S. I. Kovalets ${ }^{1}$, master student, O. S. Limarchenko ${ }^{2}$, professor, V. N. Melnik ${ }^{3}$, postgraduator

\title{
PECULIARITIES OF DEVELOPMENT OF THE GENERALIZED FARADAY EFFECT FOR SPHERICAL AND ELLIPSOIDAL RESERVOIRS
}

Класична задача Фарадея про параметричні коливання рідини у циліндричному резервуарі, що здійснює гармонічні коливання строго у вертикальному напрямку. Узагальнення класичної задачі Фарадея здійснюється в таких напрямках. Перше, рух резервуара у вертикальному напрямку розглядається не за заданим законом, а як результат дії гармонічної за часом вертикальної сили. Друге, оскільки відбувається поперечний (горизонтальний) рух рідини, допускається відповідний горизонтальний рух резервуару. Третє, розглядається резервуар нециліндричної форми. Четверте, задача розглядається в рамках нелінійної моделі сумісного руху складових системи, що, зокрема, проявляється у зміні власних частот. Аналізуються особливості поведінки системи.

Классическая задача Фарадея о параметрических колебаниях жидкости в цилиндрическом резервуаре, совершающем гармонические колебания строго в вертикальном направлении. Обобщение классической задачи Фарадея выполняется в таких направлениях. Во-первых, движение резервуара в вертикальном направлении рассматривается не за заданным законом, а как результат действия гармонической во времени вертикальной силы. Во-вторых, поскольку происходит поперечное (горизонтальное) движение жидкости, допускается соответствующее горизонтальное движение резервуара. В-третьих, рассматривается резервуар нецилиндрической формы. В-четвертых, задача рассматривается в рамках нелинейной модели совместного движения составляющих системы, что, в частности, проявляется в изменении собственных частот. Анализируются особенности поведения системы.

\footnotetext{
${ }^{1}$ Taras Shevchenko National University of Kyiv

${ }^{2}$ Taras Shevchenko National University of Kyiv

${ }^{3}$ Taras Shevchenko National University of Kyiv
} 


\section{Introduction}

The objective of the present article is to show that the use of results of the classical Faraday problem for prediction of the dynamical behavior of rockets with liquid fuel undel longitudinal vibrations can lead to an erroneous result. First, the classical Faraday problem, which is aimed at a showing of the mechanism of parametric oscillations, is far enough from the statement of the problem about longitudinal oscillation of rockets. Since rocket motion in space is not constrained, the problem must be considered in the combined statement without the use of given law of motion of either one or another component. The main reason of this consists in the considerable difference of normal frequencies of motion from their partial values when only the independent motion of the system components is considered. For real ratio of masses of the structure and liquid, this difference can be about 50-70\%.

Modeling of the system behavior is done within the framework of the nonlinear model [1], where the combined motion of the system under longitudinal harmonically changed in time loading is considered. Before this model was separately verified on a number of problems with reservoirs of noncylindrical shapes and for the non-classical versions of the Faraday problems for cylindrical reservoirs. The problem is analyzed mostly from the generation of the transversal motion of the system due to longitudinal loading since it can cause deviation of the system from the prescribed trajectory.

\section{Mathematical model}

A mathematical model of the system is constructed based on the problem formulation following the Hamilton-Ostrogradsky variational principle with preliminary satisfying of all kinematical boundary conditions and the solvability conditions of the problem. This method and all required denotation is described in detail in [1]. Finally, the model is reduced to the system if resolving equations relative to the variables $a_{i}$, i. e., amplitude parameters of excitation of the corresponding normal modes of sloshing and $\varepsilon_{i}$ - amplitude of displacement of the reservoir in the corresponding directions. This system of variables corresponds to the number of systems degrees of freedom, therefore, it is the system of minimal dimension.

$$
\begin{array}{r}
\sum_{i} \ddot{a}_{i}\left\{V_{i r}^{1}+\sum_{j} a_{j} V_{i j j}^{2}+\sum_{j, k} a_{j} a_{k} V_{i j j k}^{3}\right\}+\ddot{\bar{\varepsilon}} \cdot\left\{\vec{U}_{r}^{1}+\sum_{i} a_{i} \vec{U}_{r i}^{2}+\sum_{i, j} a_{i} a_{j} \vec{U}_{r i j}^{3}+\sum_{i, j, k} a_{i} a_{j} a_{k} \bar{U}_{r i j k}^{4}\right\}= \\
=\sum_{i, j} \dot{a}_{i} \dot{a}_{j} V_{i j r}^{2^{*}}+\sum_{i, j, k} \dot{a}_{i} \dot{a}_{j} a_{k} V_{i j k r}^{3 *}++\dot{\vec{\varepsilon}} \cdot\left\{\sum_{i} \dot{a}_{i} \vec{U}_{i r i}^{2 *}+\sum_{i, j} \dot{a}_{i} a_{j} \vec{U}_{i j r}^{3 *}+\sum_{i, j, k} \dot{a}_{i} a_{j} a_{k} \vec{U}_{i j k r}^{4 *}\right\}- \\
\left.-g\left\{\sum_{i} a_{i} W_{i r}^{2}\right\}+\frac{3}{2} \sum_{i, j} a_{i} a_{j} W_{i j r}^{3}+2 \sum_{i, j, k} a_{i} a_{j} a_{k} W_{i j k r}^{4}\right), r=1,2, \ldots N
\end{array}
$$




$$
\begin{aligned}
& \frac{\rho}{\left(M_{l}+M_{r}\right)}\left\{\sum_{i} \ddot{a}_{i}\left[\vec{U}_{i}^{1}+\sum_{j} a_{j} \vec{U}_{i j}^{2}+\sum_{j, k} a_{j} a_{k} \vec{U}_{i j k}^{3}\right]\right\}+\ddot{\vec{\varepsilon}}= \\
& =\frac{\vec{F}}{\left(M_{l}+M_{r}\right)}-g \vec{z}_{0}-\frac{\rho}{\left(M_{l}+M_{r}\right)} \sum_{i, j} \dot{a}_{i} \dot{a}_{j}\left\{\vec{U}_{i r}^{2}+2 \sum_{k} a_{k} \vec{U}_{i j k}^{3}\right\} .
\end{aligned}
$$

This system includes the coefficient, which are computed as quadratures from the normal modes of oscillations and geometrical characteristics of the reservoirs. In addition here $M_{l}$ is the mass of liquid, $M_{r}$ is the mass of the reservoir, $\rho$ is liquid density, $g$ is the free-falling acceleration. For numerical examples we take into account 10 normal modes of sloshing, longitudinal $\varepsilon_{z}$ and transverse $\varepsilon_{x}$ motion of the reservoir, the ratio of masses of reservoir and liquid was accepted 0,2.

\section{Numerical examples}

Let us consider the process of combined parametric and forced oscillations of a liquid free surface under longitudinal tracking force, which is changed according to the linear law with doubled normal frequency of liquid oscillation relative to the first antisymmetric normal mode. We underline that this the normal frequency, but not the partial one mostly used in the study of longitudinal oscillations of rockets with liquid fuel. Comprehensive analysis of the development of liquid sloshing [2] shows that parametric mechanism of development of liquid oscillations is accompanied by the forced mechanism of oscillations, caused by displacement of the liquid mass center with respect to the point of application of the longitudinal force. Therefore, there are no domains of frequencies, where the longitudinal oscillations of the reservoir will not cause the increase of sloshing oscillations. However, only in a vicinity of doubled normal frequency we observe manifestation of the parametric oscillations.

For numerical examples, we consider small initial perturbation with respect to the first normal mode ( $2 \%$ of the radius of the reservoir) for two types of reservoirs. The first case corresponds to the spherical reservoir with the filling depth $H=0,5 R$ ( $R$ is the radius of a free surface of the liquid). The second case corresponds to the ellipsoidal reservoir compressed in the vertical direction with the semiaxes $a_{x}=2$ and $b_{y}=1$. Fig. 1 and fig. 2 show the development of liquid elevation of the reservoir wall in time and transversal velocity of motion of the reservoir in time correspondingly. Fig. 3 and fig. 4 show the same results obtained in the case of the ellipsoidal reservoir. For ellipsoidal reservoir, semiaxes are $2 R$ (relative to the horizontal direction) and $R$ (relative to the vertical direction), the filling depth is $H=0,5 R$. 
The results show that after three-four periods of liquid oscillations sloshing amplitude considerably increase due to the manifestation of two mechanisms. The first one is connected with the parametric mechanism, which is peculiar for the classical Faraday problem. The second mechanism is connected with forced oscillations and it takes place only in the case when the transversal motion of the reservoir is present. It is caused by the mass displacement in the system due to asymmetric elevation on a free surface, which promotes the generation of the moment, caused by vertical force.

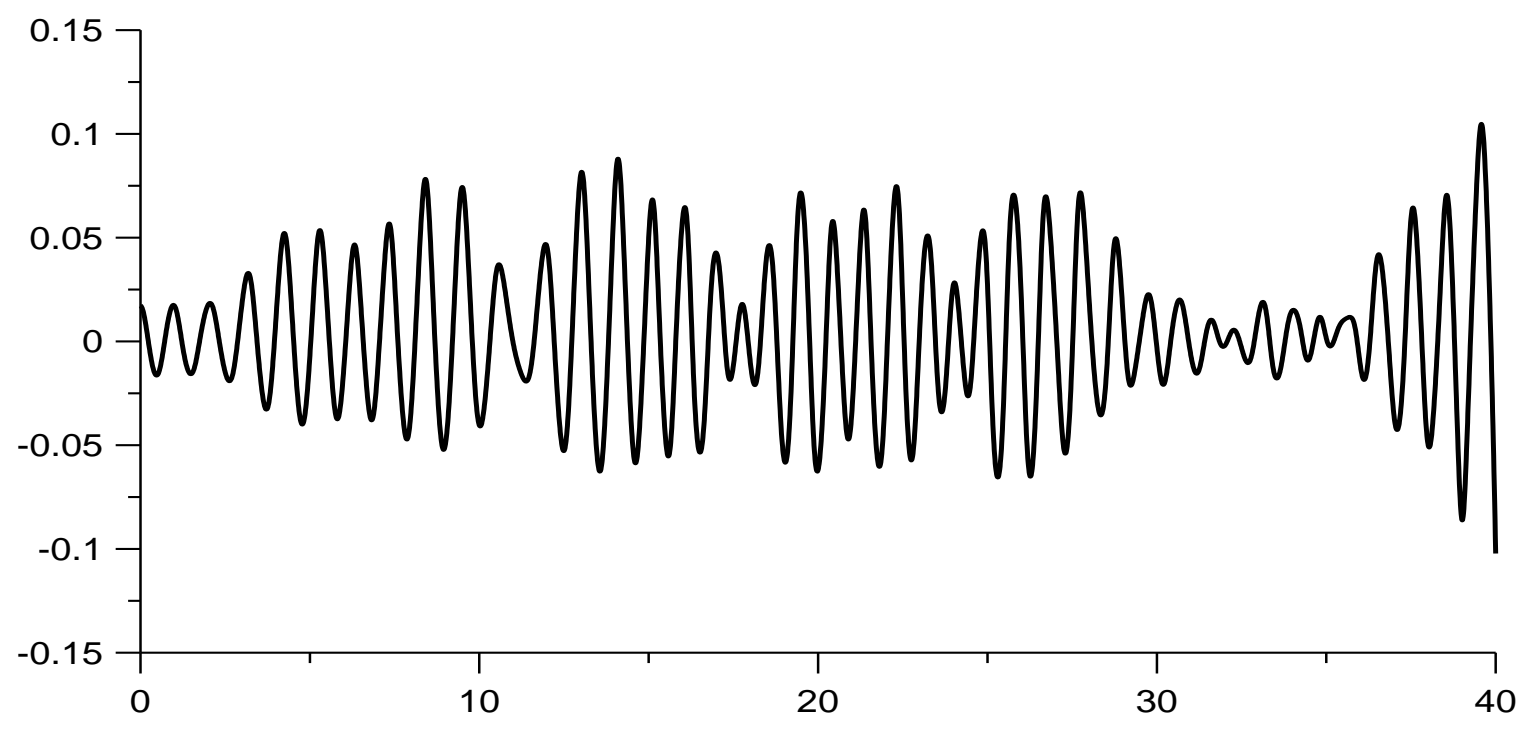

Fig. 1. Elevation of liquid on the reservoir wall

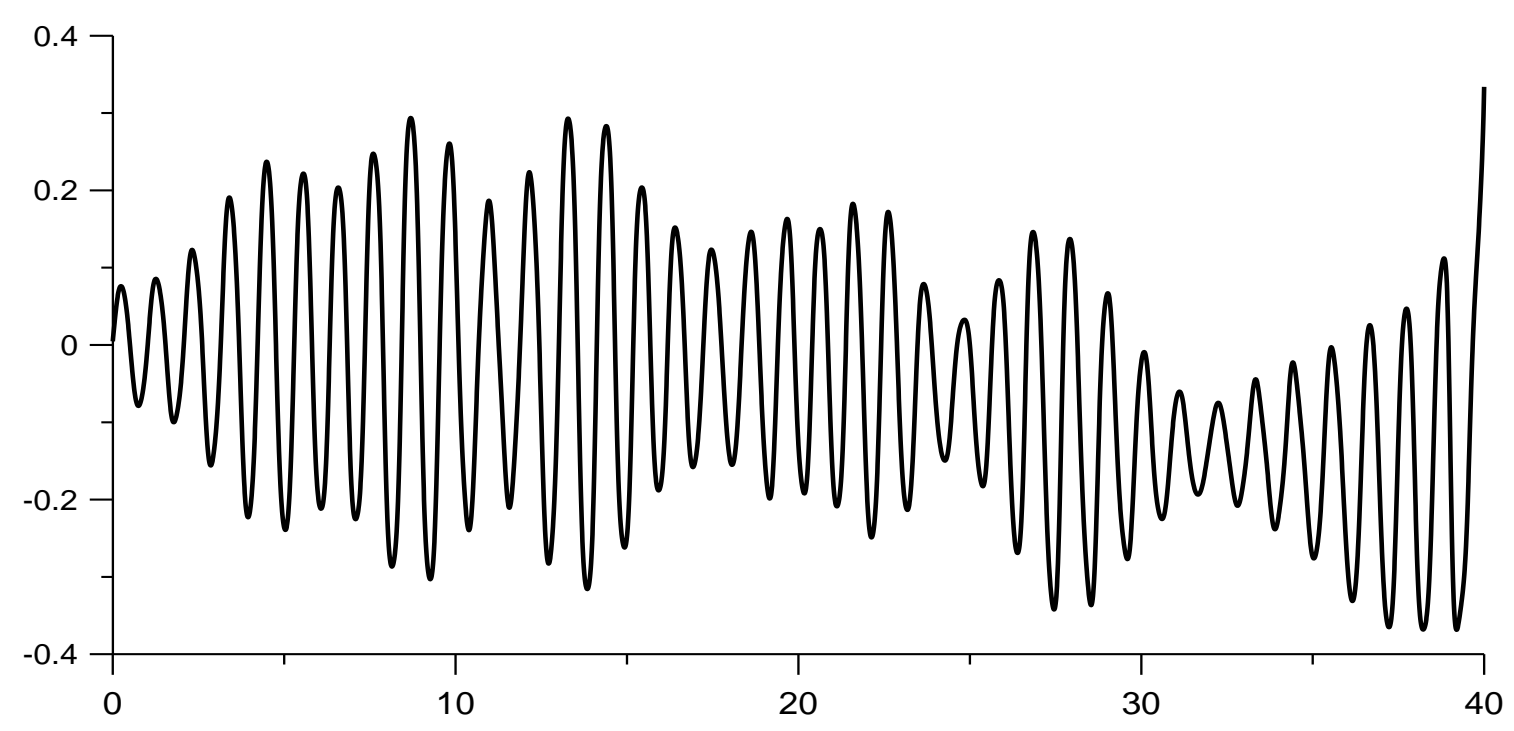

Fig. 2. Velocity of the transversal motion of the reservoir 


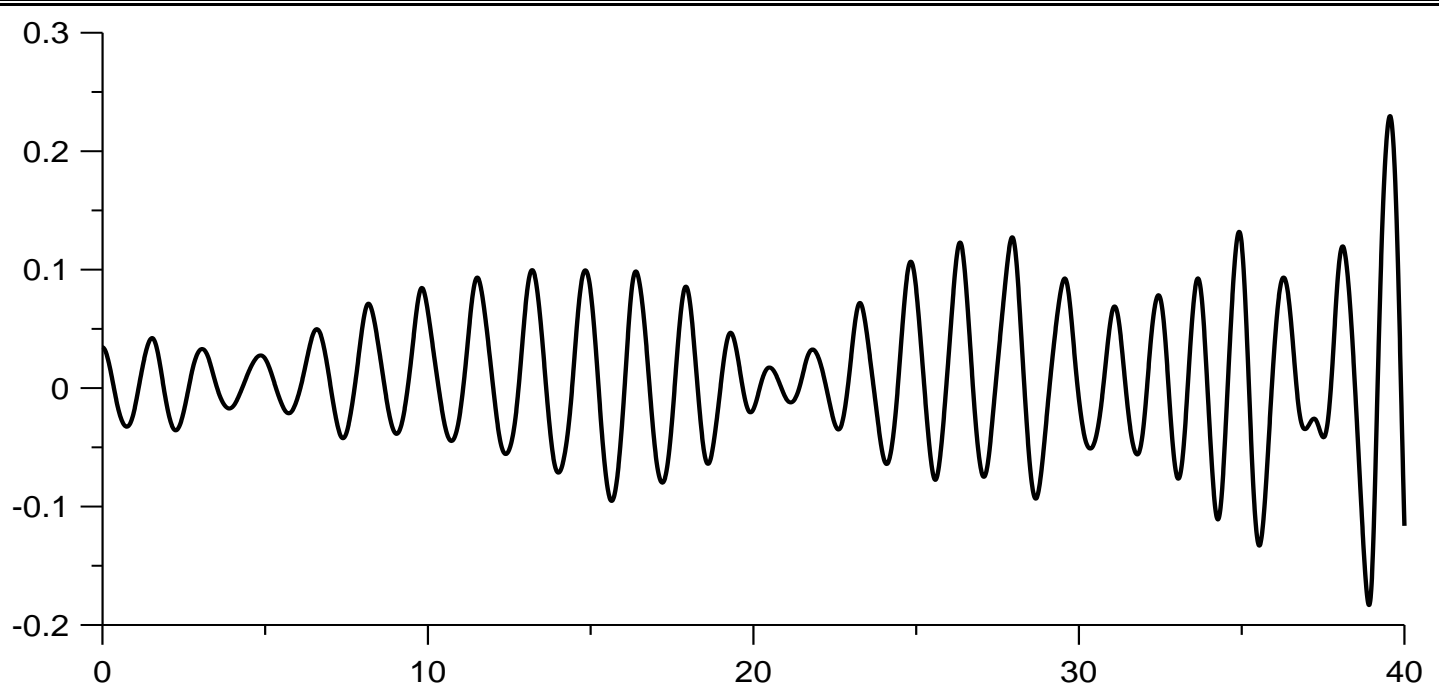

Fig. 3. Elevation of liquid on the reservoir wall

As for transversal motion of the reservoir, it increases intensively and after certain time oscillations of the reservoir obtain systematic drift from the zero position. Practically the same effects are observed for the ellipsoidal reservoir, however here the horizontal drift of the reservoir from its initial zero position is weaker. In both cases, modulation of oscillations of a free surface and velocity of the reservoir is manifested. This result is confirmed by numerous experiments connected with liquid sloshing under harmonic excitation of the reservoir motion. In contrast to the general properties of modulation, observed for transversal excitation of the system motion, here an irregular period of modulation is observed. Most probably this is caused by the impact of two different mechanisms of development of oscillations, which have two different characteristic frequencies, i.e., normal frequency of the first normal mode and its doubled value.

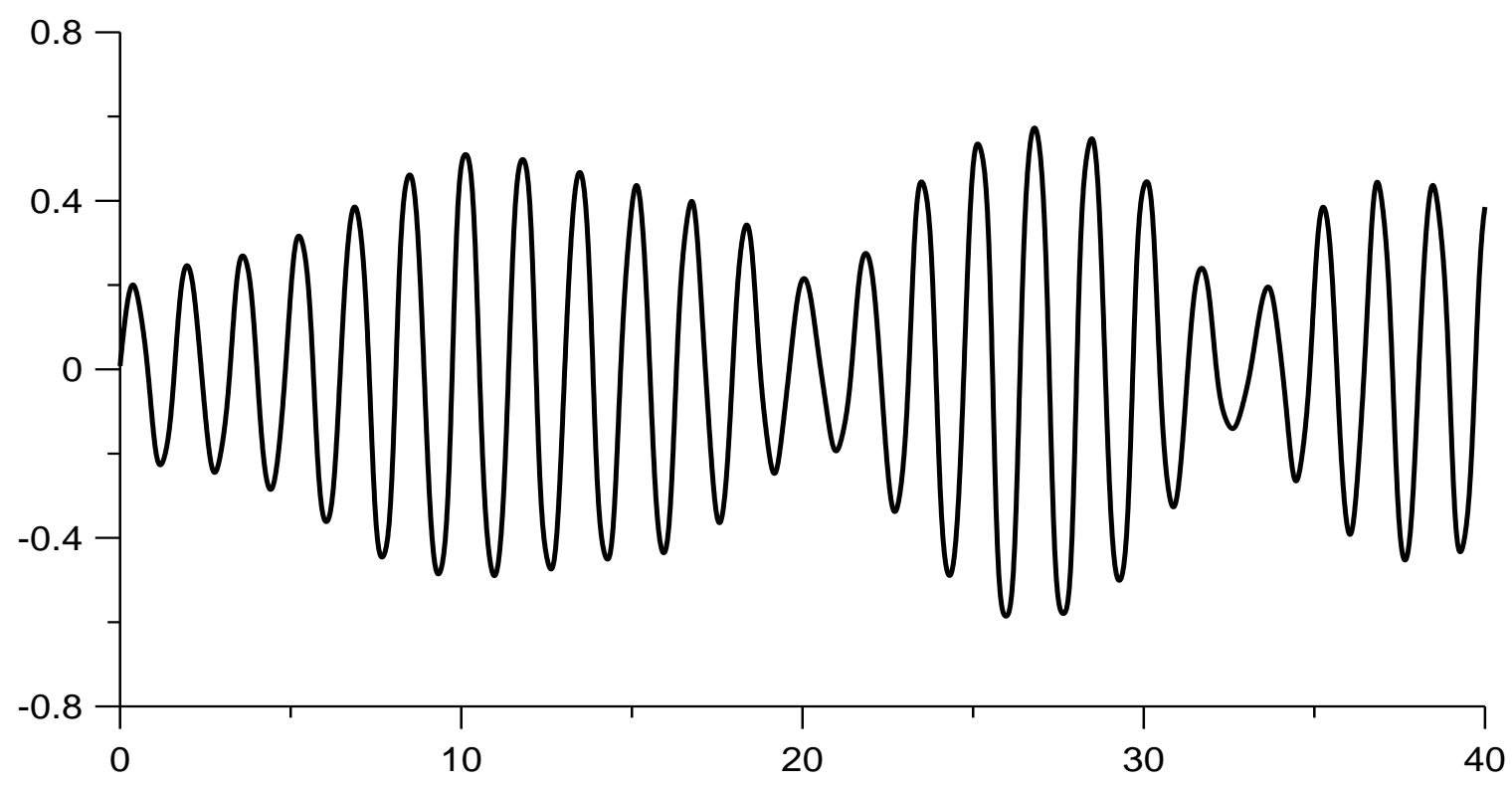

Fig. 4. Velocity of the transversal motion of the reservoir 


\section{Conclusions}

The article includes further complication of the classical Faraday problem about parametric oscillations of the reservoir with a free surface liquid. In contrast to the classical problem, we consider two variants on non-cylindrical shapes of the reservoir. Oscillations are promoted due to not kinematic excitation of the reservoir vertical motion but it is caused by the action of a longitudinal force. The transversal motion of the reservoir is not constraint. Therefore, the problem is considered within the framework of the combined problem statement. Some general properties of wave generation and transversal motion of the reservoir are analyzed.

\section{Reference}

1. Limarchenko O.S. Peculiarities of application of perturbation techniques in problems of nonlinear oscillations of liquid with a free surface in cavities of non-cylindrical shape / O. S. Limarchenko // Ukr. Math. Journ. - 2007. - 59, n. $1 .-$ P. $44-70$.

2. Konstantinov A. V. Problem about parametric oscillations of the reservoir of non-cylindrical shape with a liquid with a free surface/ A. V. Konstantinov, O. S. Limarchenko, V. N. Melnik, I. Yu. Semenova // Applied Mechanics. 2016. - 52, n. 6. - P. $49-57$. 